\title{
Буддизм в Интернете: возможности и препятствия
}

\author{
Бато Ц. Дондуков, Галина П. Дондукова
}

Восточно-Сибирский государственный университет технологий и управления, Российская Федерация

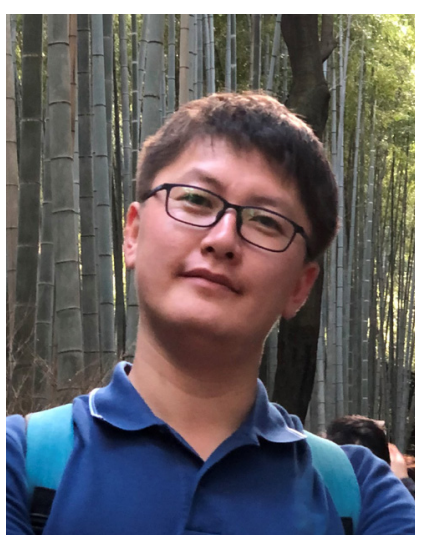

Данная статья посвящена изучению влияния принципов буддийских школ России (тибетской, дальневосточной, южной) на развитие и распространение буддийского учения в интернет-пространстве. Рассматривается активность буддийских сообществ в русскоязычном интернете от размещения текстового и медиаконтента до симуляции совместных практик посредством трансляций в режиме реального времени. Авторы пытаются выявить причины разной степени вовлеченности различных буддийских сообществ в процесс освоения Интернета. Так, в силу закрытости определенных тантрических учений тибетский буддизм препятствует использованию Интернета общинами данной традиции, в то время как дальневосточная традиция делает упор на живой контакт с учителем. В свою очередь южный буддизм в виду своих особенностей, заключающихся в приоритетности текстового познания, имеет преимущества в использовании интернет-пространства.

Авторы также рассматривают как буддийские сообщества России, включая традиционные, адаптировались к переходу в онлайн-среду в ответ на чрезвычайную ситуацию в мире, вызванную пандемией коронавируса. Подчеркивается, что лидеры

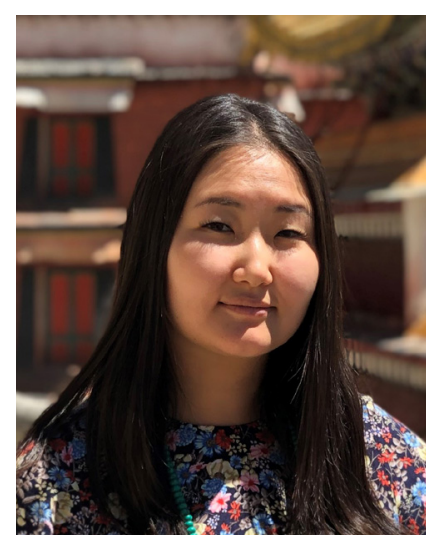
буддизма сосредоточили внимание не столько на расширении круга последователей и распространении буддийских практик, сколько на глобальных проблемах, преимущественно связанных с экологией.

Ключевые слова: религия в Интернете; буддизм в Интернете; буддийские практики; тантра; дзэн; Махаяна; Тхеравада; буддизм России

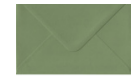

Дондуков Бато Цыренович - доктор религиоведения и культурологии ( $\mathrm{hhD})$, старший научный сотрудник Управления научными исследованиями Восточно-Сибирского государственного университета технологий и управления. Адрес: 670013, Россия, г. Улан-Удэ, ул. Ключевская, д. 40в. Тел.: +7 (3012) 43-14-15. Эл. адрес: dondukovb@gmail.com

Дондукова Галина Петровна - доктор литературоведения (PhD), кандидат филологических наук, старший научный сотрудник Управления научными исследованиями Восточно-Сибирского государственного университета технологий и управления. Адрес: 670013, Россия, г. Улан-Удэ, ул. Ключевская, д. 40в. Тел.: +7 (3012) 43-14-15. Эл. адрес: galina. dondukova11@gmail.com 


\title{
Buddhism on the Internet: Opportunities and Obstacles
}

\author{
Bato Ts. Dondukov, Galina P. Dondukova
}

East Siberia State University of Technology and Management, Russian Federation

\begin{abstract}
The article considers the principles of the Buddhist schools in Russia (such as the Tibetan, Far Eastern and Southern ones) and their influence on the development and dissemination of Buddhist teaching in the cyberspace. The authors discuss the activities of Buddhist communities in the Russian segment of the Internet that vary from uploading text and media content to simulation of joint practices through real-time streaming. They try to identify the reasons why various Buddhist communities have different degrees of involvement in assimilating the Web. For instance, due to the closed nature of certain tantric teachings, Tibetan Buddhism prevents the communities of this tradition from using the Internet, while the Far Eastern tradition focuses on live contact with the teacher. In turn, Southern Buddhism - as a result of its features, such as the priority of textual cognition - has advantages in using the Internet space.

The authors also examine how Russia's Buddhist communities, including traditional ones, have adapted to the transition to the online environment in response to the global emergency caused by the coronavirus pandemic. Moreover, the leaders of Buddhism have focused more on global (especially ecological) problems rather than increasing the number of followers or spreading Buddhist practices.
\end{abstract}

Keywords: religion on the Internet; Buddhism on the Internet; Buddhist practices; Tantra; Zen; Mahayana; Theravada; Buddhism of Russia

Financing

The article was prepared within the framework of the project no. 19-18-00412 supported by the Russian Science Foundation.

DONDUKOV, Bato Tsyrenovich, PhD in Culture and Religion Studies, Senior Research Assistant, Department of Organization and Management of Scientific Research, East Siberia State University of Technology and Management. Postal address: 40в, Klyuchevskaya St., 670013 Ulan-Ude, Russian Federation. Tel.: +7 (3012) 43-14-15. E-mail: dondukovb@ gmail.com

DONDUKOVA, Galina Petrovna, PhD in Literary Studies, Candidate of Philology, Senior Research Assistant, Department of Organization and Management of Scientific Researches, East Siberia State University of Technology and Management. Postal address: 40в, Klyuchevskaya St., 670013 Ulan-Ude, Russian Federation. Tel.: +7 (3012) 43-14-15. E-mail: galina.dondukova11@gmail.com 


\section{Введение}

Статья посвящена изучению особенностей освоения русскоязычного Интернета буддистскими общинами как локальными, так и глобальными, которые уже более 20 лет присутствуют в той или иной степени в цифровой среде. На сегодняшний день ${ }^{1}$ можно обнаружить более 150 буддийских сайтов, а количество ресурсов в социальных сетях, учитывая высочайшую динамику их развития, и вовсе не поддается подсчету.

Говоря о буддизме в России, необходимо отметить широкое разнообразие сообществ, отличающихся не только формой существования, но и принадлежностью к различным направлениям и традициям буддизма. История буддизма в России насчитывает более четырехсот лет с момента включения в свой состав народов, исповедовавших тибетскую традицию буддизма: калмыки в XVII в., буряты - в XVIII веке и тувинцы - в XX веке. Сегодня республики Бурятия, Калмыкия и Тува представляют традиционные буддийские регионы России. Помимо тибетской традиции, с которой Россия знакома давно, существуют также дальневосточная и южная традиции буддизма, широко распространившиеся по всей России в виде общин и так называемых дхарма-центров (Нестеркин, 2009: 18). Все эти буддистские сообщества действуют преимущественно обособлено, имеют принципиальные отличия и по-разному подходят к использованию Интернета: одни проявляют высокую активность, другие не уделяют ему большого внимания.

Цель данной статьи - изучить насколько буддизм, его особенности и сакральные практики помогают или препятствуют развитию и распространению буддийского учения в интернет-пространстве России, а также рассмотреть, как буддийские сообщества России адаптировались к переходу в онлайн-среду в связи с глобальной пандемией коронавируса.

Первая часть статьи будет посвящена анализу особенностей каждой из традиций буддизма, так как, по нашему мнению, именно эти внутренние особенности школ буддизма имеют высокое влияние на потенциал использования Интернета. Такой анализ позволит ответить на ряд вопросов: в каком объеме виртуальное пространство может удовлетворять религиозные потребности буддистов? С какими интернет-ресурсами мы имеем дело сегодня и какие религиозные особенности препятствуют или способствуют переносу буддийских практик в Интернет? Далее мы рассмотрим изменения, которым подвергся буддизм в Интернете в связи с пандемией коронавируса, и попытаемся осмыслить новые трансформации в рамках уже начавшегося процесса цифровизации буддизма в России.

\section{Тибетский буддиз: тантра как препятствие}

На просторах Интернета опубликовано колоссальное количество буддийских книг, лекций как целиком, так и в виде выдержек, публикуемых в формате постов в социальных сетях. Также можно встретить огромное количество информации в виде объявлений о предстоящих мероприятиях или новостей буддийского мира. Однако, в рамках данной статьи мы не будем сосредотачивать внимание на подобном контенте, поскольку, на наш взгляд, это не сильно отличается от офлайн чтения общедоступных книг или публикации новостей в прессе. В гораздо большей мере нас интересует сторона переноса буддийских практик в онлайн-пространство (Campbell, 2013; Grieve, Veidlinger, 2014).

Рассматривая особенности тибетского буддизма, мы обратили внимание на веб-трансляции учений в режиме реального времени. Обычно, проводимые буддийскими гуру современные учения представляют собой не только лекции о буддийской философии, призванные повлиять на людей на уровне взглядов, но имеют и сакральное значение. Считается, что соприкосновение с учением и со святыми учителями само по себе приносит кармические заслуги, закладывая трансформации индивида на тонком уровне.

Перенос сакрального в виртуальную среду воспринимается неоднозначно, так как для многих, особенно последователей старшего поколения, переход в цифровую среду предполагает потерю сакрального времени и пространства (Aupers, Houtman, 2010). Однако, еще с начала 2000-х годов многие гуру, имеющие мировую известность, такие как Его Святейшество XIV Далай-лама, XVII Кармапа Оргьен Тинлей, Оле Нидал и другие, периодически практикуют онлайн-трансляцию своих учений. Это связано с большой территориальной разбросанностью многочисленных последователей по всему миру, которые в силу различных обстоятельств зачастую не могут физически присутствовать на

\footnotetext{
${ }^{1}$ По данным января 2021 г.
} 
учениях. В декабре 2010 г. на официальном сайте Центра тибетской культуры и информации (savetibet.ru) была опубликована статья, в которой Далай-лама и Кармапа Оргъен Тинлей Дордже выразили свои мнения относительно трансляций учений. Далай-лама заявил следующее:

«Мы будем транслировать ... предварительное посвящение в тантру Гухьясамаджи до момента вступления в мандалу, так как я считаю неправильным транслировать основную часть посвящения. В самом тексте тантры сказано, что, прежде чем даровать это посвящение, наставник должен сперва проверить, восприимчивы ли его ученики к данному учению или нет» ${ }^{1}$.

Из речи Далай-ламы мы видим, что лидеры буддизма намеренно ограничивают онлайн-трансляцию, когда речь заходит о тантрическом уровне тибетского буддизма. Подобный принцип наблюдается и у других буддийских учителей. Другими словами, краеугольным камнем онлайнтрансляции буддийских учений является тантра.

Путь тантры, который также именуется Ваджраяна, связан с эзотерическими мистическими практиками. С точки зрения тибетского буддизма, практика тантры считается наиболее эффективной для достижения просветления и в то же время наиболее опасной, поскольку без серьезного подхода и правильного понимания может привести к тяжелым негативным последствиям для практикующего в кармическом и даже физическом плане (Торчинов, 2000). Передача тантрических практик ученикам является ответственным шагом, поскольку несет риск как для неподготовленного человека - ученика, так и для кармы учителя. Поэтому в обеты практиков тантры включен запрет на свободное распространение тантрических учений, а его нарушение является одним из серьезнейших проступков (Berzin, 1997). В Ваджраяне существуют традиции, затрудняющие доступ к тантрическим практикам. Например, для доступа к определенным уровням тантры адепт должен завершить подготовительную практику «Нёндро», в рамках которой совершается 100 тысяч повторений определенных действий, таких как простирание, чтение мантр, подношение мандал и др. Такая практика требует высокой степени усердия и может длиться несколько лет. Помимо кармического очищения, на данном этапе отсекаются люди, не имеющие серьезных намерений практиковать тантру ${ }^{2}$

Следует отметить, что обряды инициации в тантрические практики, включающие совместную медитацию, визуализацию и устную передачу, подразумевают не только предоставление допуска, но и передачу энергии учителя, который в свою очередь получил ее от своего учителя. Так сохраняется линия преемственности, восходящая к самому Будде (Андросов, 2011: 265). Изначально в рамках монастырской системы практики передачи происходили между учителем и монахом индивидуально, однако современная деятельность множества буддийских учителей на Западе, создала тенденцию упрощения некоторых буддийских практик, где гуру дает посвящения множеству людей, собравшимся на учениях уже вне монастырей (Аюшеева, 2013: 124).

Существует ли возможность полноценной тантрической передачи посредством компьютерных сетей? В целом, на сегодня не существует единого мнения по поводу использования Интернета для подобных практик, и буддийские учителя подходят к данной возможности по-разному. В своем заявлении Кармапа XVII отмечает, что нельзя с уверенностью говорить о том, можно ли получить посвящение на расстоянии через современные средства коммуникации:

«Не стоит превращать получение посвящений через Интернет в устоявшуюся традицию. Вспомните о тех огромных трудностях, сопряженных с дальней дорогой, которые в давние времена приходилось преодолевать ученикам, желающим получить тантрическое посвящение. Перенесенные трудности закаляли сердце ученика, помогая ему упрочиться в преданности учителю, что имеет особый смысл. Едва ли это произойдет, если вы будете просто сидеть перед монитором»³.

Как видим, важным аспектом тантрических практик являются усилия, прилагаемые для получения учений, в то время как интернет-технологии, наоборот, применяются для упрощения и ускорения

\footnotetext{
${ }^{1}$ Далай-лама и Кармапа выразили мнение о трансляции буддийских посвящений в Интернет [Электронный ресурс] // Сохраним Тибет! Тибет, Далай-лама, буддизм. 2010, 13 декабря. URL: http://savetibet.ru/2010/12/13/ buddhism.html (дата обращения: 12.07.2018).

${ }^{2}$ The Main Features of Tantra. [Электронный ресурс] // Study Buddhism by Berzin Archives. URL: https:// studybuddhism.com/en/advanced-studies/vajrayana/tantra-theory/the-main-features-of-tantra (дата обращения: 20.11.2018).

${ }^{3}$ Далай-лама и Кармапа выразили мнение о трансляции буддийских посвящений в Интернет [Электронный ресурс] // Сохраним Тибет! Тибет, Далай-лама, буддизм. 2010, 13 декабря. URL: http://savetibet.ru/2020/05/18/ dalai-lama.html (дата обращения: 12.07.2018).
} 
доступа. Таким образом, создается противоречивая ситуация, где, с одной стороны, многочисленные ученики со всего света получают доступный способ соприкосновения с учением, но в то же время в перспективе это грозит утратой важного аспекта духовного пути адепта, связанного с усердием в постижении буддизма.

В процессе изучения сайтов тибетского буддизма в русскоязычном интернете нам удалось выявить, что дальше остальных в осуществлении удаленных буддийских практик зашел известный буддийский учитель школы Ньингма, Намкай Норбу Ринпоче, основавший сеть международных буддийских общин Дзогчен. Еще в 2000-м году Намкай Норбу объявил об организации дистанционной «Всемирной практики гуру-йоги». Для организации мероприятия были подготовлены видеокассеты с инструкциями на разных языках, которые рассылались в представительства общины по всему миру, а практики по ним синхронизировались по времени. Свое решение Ринпоче аргументировал тем, что «учения существуют вне времени и пространства, поэтому территориальная отдаленность не является препятствием к совместным практикам... Мы устанавливаем связь, пребываем в одном состоянии в один и тот же миг - именно так бывает при получении передачи» ${ }^{\text {. }}$

Позже с развитием интернет-сервисов создается сайт веб-трансляций буддийских учений и ретритов $^{2}$. С тех пор количество практик через веб-трансляцию увеличивается, появляется традиция трансляций более серьезных уровней практики. Помимо трансляций на сайтах общины также публикуются тантрические тексты и изображения, однако доступ к ним имеют только зарегистрированные пользователи. Регистрация на сайте требует членства в общине, включающего членские взносы. Для полного доступа к контенту требуется непрерывное членство в общине на протяжении трех лет, что обеспечивает фильтрацию случайных людей.

Подобная организация доступа к тантрическим текстам онлайн обнаруживается и среди российских буддийских общин. Речь идет о сайте kalachakra.ru, созданном буддийским центром «Арьядэва» в г. Санкт-Петербург. Сайт содержит в себе тантрические тексты Калачакра тантры, и делится на 3 категории: «Общие», «Для посвященных» и «Для получавших наставления». Общие тексты находятся свободном доступе, но для того, чтобы получить доступ к следующим разделам, требуется пройти регистрацию. Регистрация содержит специфические вопросы, призванные проверить уровень пользователя. Так, например, для «получавших наставления» представлены следующие вопросы:

- У кого, когда получали наставления?

- Как называется метод осуществления (дубтаб), соединенный с шестиразовой йогой в одну расширенную практику?

- Значение имени Круга Времени

Ответить на данные вопросы обывателю представляется невозможным. Важно отметить, что в данном случае хранение тайных текстов осуществляется функцией сервера, а доступ к нему предоставляется уже не учителем, а программным кодом. В связи с этим возникают вопросы, которые остаются на сегодняшний день открытыми: является ли знание ответов на вышеуказанные вопросы исчерпывающим критерием? Возможно ли создать алгоритмы оценки, которые обеспечат программы способностью принимать решение касательно предоставления доступа пользователей к тантрическим практикам?

Говоря о тибетском буддизме, необходимо сказать и о традиционных буддийских общинах России. Так, у Буддийской традиционной сангхи России есть свой сайт - sangharussia.ru, khuruul.ru сайт Объединения буддистов Калмыкии. У тувинских буддийских организаций также имеются свои сайты, такие как dharma.tuva.ru и tuvalobdon.com. Анализ этих сайтов показывает, что данные организации являются наименее активными в освоении интернет-среды (Дондуков, 2019). Это объяснимо, учитывая территориальную близость лам со своими последователями, что не стимулирует развитие удаленных коммуникаций. Традиционно сангха в буддийских регионах занимается развитием своих храмов, окружена многочисленной паствой и с прихожанами работает при личных

\footnotetext{
${ }^{1}$ Всемирная практика [Электронный ресурс] // Дзогчен община. URL: http://www.kunsangar.org/vsemirnayapraktika/ (дата обращения: 12.07.2018).

${ }^{2}$ http://webcast.dzogchen.com/

${ }^{3}$ http://kunsangar.org, http://rinchenling.ru/

${ }^{4}$ Регистрация [Электронный ресурс] // Калачакра - Круг времени. URL: https://kalachakra.ru/registration/ (дата обращения: 24.04.2015).
} 
встречах. Следует также учитывать, что посещение храма считается благотворным актом для мирян, тем более в регионах традиционного буддизма. К тому же, находясь в условиях восстановления после советского режима, традиционные буддийские сообщества России не тяготеют к экспансии.

\section{Дальневосточный буддизм: истина вне текста}

Помимо сайтов тибетского буддизма в русскоязычном Интернете также представлены сайты дальневосточного буддизма, преимущественно посвященные школе дзэн. Данная школа достаточно сильно отличается от других традиций буддизма, в первую очередь своим отношением к текстовому и аналитическому познанию. Дзэн имеет слабую связь со священными писаниями, считая философские рассуждения бесполезными. В рамках школы дзэн утверждается, что истина не может быть выражена в словах, которые являются лишь «намёком на истину» (Померанц, Миркина, 2006: 148). Один из ведущих мировых популяризаторов дзэн, профессор философии Дайсэцзу Тэйтаро Судзуки отмечает: «...все буддийские учения, содержащиеся в сутрах и шастрах, с точки зрения дзэн не больше, чем макулатура, польза которой состоит лишь в том, что с её помощью можно только смахнуть пыль с интеллекта» (Судзуки, Кацуки, 1993: 25). Таким образом, в дзэн-буддизме роль учителя очень высока и опыт живой практики является ключевым, в отличие от лекций и текстов.

Описанный принцип дзэн-буддизма наиболее сильно оказывает влияние на степень использования виртуального пространства общинами данной школы. Создание ресурсов для распространения текстов дзэн не представляет особой важности, а веб-трансляции учений в современном виде вряд ли смогут воссоздать эквивалентные условия для эффективной работы с учениками.

Обзор русскоязычных сайтов, посвященныхдзэн-буддизму, показал, что в России преимущественно развиты школы, являющиеся частью крупных международных общин, таких как Кван Ум. Сайты этих общин имеют схожие черты и преимущественно содержат оповещения о мероприятиях, происходящих в этих центрах. Анализ контента сайтов подтверждает гипотезу о влиянии основного принципа дзэн на степень использование Интернета. В разделах с теоретической информацией часто встречается упоминание о том, что текстовая информация не поможет овладеть пониманием дзэн и способна лишь мотивировать участников на поиск живого общения с учителем. Приведем несколько примеров.

На сайте общины Кван Ум в разделе текстов сказано следующее:

«Нижеприведенные статьи дадут некоторое представление о практике в Школе дзэн Кван Ум, но лучше осваивать практику и разбираться в деталях под руководством опытных практикующих в дзэн-центрах и на ретритах, так как текст не может осветить всех тонкостей и заменить живую практику» ${ }^{.}$

На сайте Санкт-Петербургского Дзэн-центра в разделе «Библиотека» приведена такая цитата:

«В книгах можно найти массу ценной информации и верных указаний. Однако, найти свою истинную природу невозможно без помощи живого учителя. В силу особенностей нашего ума, ученики смотрят на указывающий палец, а не на то, куда он указывает. Только учитель может увидеть, куда направлен взгляд ученика, взять его за подбородок и поднять ему голову, чтобы ученик смотрел не на палец, не на учителя, а на луну, куда палец указывал»².

Таким образом, интернет-ресурсы общин дзэн-буддизма призваны побудить пользователей посетить их центры и соприкоснуться с живым общением с действующими там мастерами. В данном случае мы можем сказать, что принципы данной школы делают невозможным полный переход деятельности общин в виртуальное пространство, по крайней мере на данном этапе развития интернет-технологий.

\section{тхеравада: текст как истина}

Буддизм Тхеравады, также известный как южный буддизм, фундаментально отличается от традиций тибетского и дальневосточного буддизма. В данной статье мы не будем углубляться в

\footnotetext{
${ }^{1}$ Начинающим [Электронный ресурс] // Школа Дзэн Кван Ум. URL: http://kwanumzen.ru/zen/forbeginners/ (дата обращения: 13.08 .2018$)$.

${ }^{2}$ Библиотека [Электронный ресурс] // Дзэн - путь к себе: O ZenDao, пути к себе и о себе. URL: https://zendao.ru/ library (дата обращения: 13.08.2018).
} 
разбор отличий данной традиции буддизма, а сосредоточимся на принципе Тхеравады, который наибольшим образом влияет на освоение интернет-пространства общинами данной школы.

В буддизме Тхеравады отсутствует тантра и другие эзотерические методы, отсутствует традиция внетекстового познания, в то время как тексты, напротив, представляют наивысший авторитет и ценятся выше учителей и методов практики. Неудивительно, что интернет-пространство используется российскими общинами Тхеравады в основном для публикации текстов Палийского канона, основы южного буддизма, нежели для медитации или трансляции сакральных учений гуру. Сайты Тхеравады ${ }^{1}$ в большей степени наполнены буддийской информацией, чем сайты других школ буддизма. При этом, если тексты на сайтах других традиций преимущественно представляют собой публикации книг, основанных на адаптированных лекциях, читаемых учителями на Западе, то на сайтах Тхеравады основной упор делается на публикациях текстов из Палийского канона в структурированной форме.

Представлены три традиционных раздела - сутта, виная и абхидхамма - с множеством подразделов, в которых тексты представлены с пометками согласно системе нотаций цитат канона. В качестве примера приведем сутту из подраздела, «Ангуттара Никая»:

АН 1.22 Дутия сутта: Вторая

[Благословенный сказал]: «Монахи, я не вижу ни одной другой вещи помимо (1) ума, которая, будучи развитой, была бы настолько податливой. Развитый ум является податливым»².

Четкая структура и формулировка текстов буддийского канона на сайтах Тхеравады позволяет пользователям хорошо в них ориентироваться и дает возможность последовательного постижения вероучения. Можно утверждать, что буддизм Тхеравады не испытывает проблем с переходом в интернет-пространство в отличие от других традиций буддизма, например, с веб-трансляцией сакрального или публикациями тайных текстов. Однако, вместе с важностью изучения текстов Палийского канона, как наиболее аутентичного источника буддизма, буддизм Тхеравады подчеркивает значение монашеского пути как наиболее приближенного к пути Будды Шакьямуни. Поэтому невозможно сказать, что функционирование буддизма Тхеравады может быть полностью переведено в онлайн-режим.

\section{Буддизм в Интернете в период пандемии COVID-19}

Описанное выше положение дел отражает ситуацию до пандемии COVID-19. В 2020 г. пандемия коронавируса затронула все группы людей, включая буддийские религиозные сообщества России. Сообщения о том, что буддийские ламы заболели коронавирусом, поступали из разных буддийских регионов страны. В июне 2020 г. буддийский мир потрясла новость о смерти от коронавируса Камбы ламы Тувы (глава буддизма Тувы) Башкы Джампел Лодоя, которому было 44 года. Данный случай напомнил как духовенству, так и мирянам об ответственном отношении к живым контактам. Когда посещение буддийских храмов и общественных мест стало рискованным, а в некоторых случаях попросту невозможным, общины и буддийские лидеры были вынуждены использовать интернеттехнологии (Гаврилова, Жиронкина, 2020; Shoji, Matsue, 2020).

Сегодня, если зайти на сайт Центра тибетской культуры и информации savetibet.ru, являющимся одним из наиболее популярных новостных ресурсов тибетского буддизма, можно увидеть, что подавляющее число заголовков новостной ленты содержит оповещения об учениях и посвящениях онлайн, проводимых разными учителями. Просмотрев множество объявлений на сайте, мы не нашли дискуссий относительно возможности получения посвящения через Интернет. Такое состояние дел скорее всего говорит о том, что в новых условиях пандемии данный вопрос считается решенным. Более того, посвящение стало допускаться уже не в режиме трансляции, а в режиме просмотра записи в любое время.

В объявлении о посвящении Авалокитешвары, которое проводилось Далай-ламой 29-30 мая 2020 года, говорится следующее:

\footnotetext{
${ }^{1}$ http://theravada.ru/, https://www.theravada.su/

2 Дутия сутта: Вторая Ангуттара Никая 1.42 [Электронный ресурс] // Буддизм южной традиции: Тхеравада.ру. URL: http://www.theravada.ru/Teaching/Canon/Suttanta/Texts/an1_42-dutiya-sutta-sv.htm (дата обращения: 30.08.2018).
} 
«Самое важное для получения посвящения - это мотивация. Те, кто по какой-то причине не сможет принять участие в прямой трансляции, смогут получить посвящение, посмотрев трансляцию в записи, при условии правильной мотивации» ${ }^{\text {. }}$

В объявлении о посвящении Хеваджры, которое проводилось Гарченом Ринпоче 23-24 января 2021 г., также говорится, что получение любого посвящения через прямую трансляцию (и даже путем просмотра записанного видео), в сочетании с мотивацией бодхичитты, может быть благотворным ${ }^{2}$ Таким образом, можно предположить, что в современной интерпретации энергия, передаваемая от учителя к ученику, не передается в рамках общего физического пространства и времени, а скорее является неким внутренним качеством, которое зарождается у созревшего к получению посвящения индивида при просмотре записи. Из приведенной цитаты можно заключить, что при неправильной мотивации посвящение не происходит, а значит, ответственность за получение онлайн-посвящения теперь возлагается на самих учеников.

Учителя дзэн-буддизма не сменили риторики касательно текстового познания и продолжают призывать к живому общению, однако теперь они говорят о том, что онлайн-трансляции могут считаться живым общением ${ }^{3}$ Тем не менее, в социальных сетях и на сайтах буддийских общин нам удалось обнаружить лишь два оповещения о трансляции учений. Можно предположить, что лишь некоторые учителя пытаются адаптироваться к сложившейся ситуации.

В общинах Тхеравады изменений не замечено, как и не замечено заявлений о ситуации с пандемией. Присутствуют объявления о закрытии центров, однако способы какой-либо адаптации учений к интернет-пространству в связи с пандемией коронавируса отсутствуют.

В процессе изучения удалось зафиксировать и другую сторону последствий глобального кризиса. Впервые на сайтах российских буддийских общин появились объявления об онлайн-сборах пожертвований на содержание дхарма-центров и храмов. Так, Санкт-Петербургский дацан Гунзэнчойнэй объявил о трудном положении из-за отсутствия посетителей в связи с пандемией, вследствие чего храм лишился средств на оплату коммунальных услуг ${ }^{4}$ Община буддизма Тхеравады «Буддавихара» также разместила объявление о сборе средств на содержание центра ${ }^{5}$. Данное обстоятельство свидетельствует о важности физического посещения центров и храмов, как источника финансирования. Чрезмерный уклон в онлайн-сервисы может привести к невозможности существования реальных центров, что, на наш взгляд, является сдерживающим фактором использования Интернета буддистскими сообществами. В целом, мы видим, что общины освоили методы онлайн-сбора средств и в объявлениях об онлайн-учениях, присутствуют реквизиты для пожертвований. Однако, очевидно, данные методы не могут в эквивалентном размере удовлетворять всем потребностям буддийских центров.

Другими словами, если до пандемии, использование Интернета допускалось, но подвергалось ограничениям со стороны разных лидеров, то новая ситуация спровоцировала резкий всплеск использования Интернета, сопровождающийся упрощением и адаптацией буддийских практик. С одной стороны, можно предположить, что адаптация происходит из-за потребности в постоянном контакте с последователями. С другой стороны, заявления буддийских лидеров касательно пандемии показывают и другой важный аспект. Продвигая онлайн-практики, буддийские учителя подчеркивают важность социальной дистанции и изоляции. Далай-лама отмечает, что «у сострадательного или созидательного поступка, - будь то работы в больницах или просто соблюдения социальной дистанции, - есть потенциал оказать помощь многим» ${ }^{6}$. Лама Сопа в своем обращении также под-

\footnotetext{
${ }^{1}$ Запись прямой трансляции. Далай-лама. Посвящение Авалокитешвары [Электронный ресурс] // Сохраним Тибет! Тибет, Далай-лама, буддизм. 2020, 18 мая. URL: http://savetibet.ru/2020/05/18/dalai-lama.html (дата обращения: 30.01.2021).

${ }^{2}$ Гарчен Ринпоче дарует посвящение Хеваджры и Учение о «Четырех Дхармах Гампопы» [Электронный ресурс] // Сохраним Тибет! Тибет, Далай-лама, буддизм. 2021, 22 января. URL: http://savetibet.ru/2021/01/22/garchen-rinpoche. html (дата обращения: 30.01.2021).

${ }^{3}$ https://vk.com/sukoleg?w=wall144977461_2874

${ }^{4}$ Дацан Гунзэчойнэй помог десяткам тысяч людей. Но сегодня храм сам нуждается в помощи! [Электронный ресурс] // BКонтакте. URL: https://vk.com/dazanspb?w=wall-1142099_24469 (дата обращения: 30.01.2021).

${ }^{5}$ Поддержите Буддавихару [Электронный ресурс] // Буддизм Тхеравада в России. 2020, 2 июня. URL: https:/www. buddhavihara.ru/поддержите-буддавихару/ (дата обращения: 30.01.2021).

6 «Молитв недостаточно». Далай-лама о том, почему мы должны бороться с коронавирусом с состраданием [Электронный ресурс] // Сохраним Тибет! Тибет, Далай-лама, буддизм. 2020, 15 апреля. URL: http://savetibet. ru/2020/04/15/dalai-lama.html (дата обращения: 30.01.2021).
} 
черкивает: «Благодаря своим усилиям по изоляции мы защищаем других людей, устраняя возможность распространения вируса. Не это ли воплощение бодхичитты!» Другими словами, продвигая онлайн-формат учений, буддийские учителя пытаются призвать людей беречь свои и чужие жизни способствовать сохранению людьми социальной дистанции, что в данной ситуации становится необходимой мерой и допускает упрощение практик.

Данному выводу также способствует и то, что видные лидеры буддизма сегодня сосредотачивают внимание не столько на расширении круга последователей и распространении буддийских практик, сколько на глобальных проблемах, преимущественно связанных с экологией. Будучи неантропоцентричной религией, буддизм поддерживает этические принципы взаимодействия с миром природы, уважения и сострадания ко всем живым существам, что во многом соотносится с идеями современных экологических движений.

Далай-лама в своих обращениях по поводу пандемии подчеркивает обеспокоенность экологическим состоянием земли, в частности в связи с колоссальными изменениями климата ${ }^{2}$ В своем интервью журналу The Guardian в ноябре 2020 г, Далай-лама упомянул, что одним из вопросов первостепенной важности для него стали экологические проблемы ${ }^{3}$. XVII Кармапа Орьген Тинлей прикладывает множество сил для продвижения созданного им экологического движения «Хорьюг» ${ }^{4}$

Российские общины не остаются в стороне: буддистская ассоциация «Арья Сангха» обратила внимание на экологические проблемы и организовала в феврале 2021 г. Международную онлайнконференцию «Байкал - чистая чаша планеты».

Другими словами, если до пандемии благоприятные условия в мире позволяли сосредоточить внимание на расширении общин и распространении буддийских практик, то в условиях глобального кризиса вопросы выживания и развития экологического сознания стали приоритетной задачей мировых буддийских лидеров. В данном случае, использование интернет-пространства для распространения экологических ценностей на широкие слои общества становится достаточно перспективным и важным путем духовного развития.

\section{Заключение}

Итак, мы видим, что перенос буддийских практик в онлайн-плоскость зависит от множества факторов, как внутренних, так и внешних. На сегодня не существует какой-либо общей позиции относительно использования Интернета и каждый буддийский лидер подходит к данному вопросу исходя из личных убеждений и сложившихся условий. Рассмотрев основные особенности каждой из традиций буддизма, влияющие на освоение Интернета, мы можем заключить, что он полезен для буддийских сообществ с точки зрения доступности, однако доступность не всегда является полезной для буддийских практик. В случае с тибетским буддизмом доступность несет в себе риски и приводит к утрате важных аспектов буддийского пути. С точки зрения дзэн-буддизма, использование Интернета не может предоставить условий, эквивалентных живому общению. С точки зрения Тхеравады отсутствуют разного рода препятствия для онлайн-деятельности, однако по причине важности монашеского пути, практика в Интернете не может претендовать на полноценную.

В целом проблема освоения интернет-пространства буддийскими сообществами - это преимущественно проблема глобализации буддизма. Вокруг видных буддийских деятелей создаются дхарма-центры по всему миру. При этом сами сообщества приспосабливают монашеские религиозные практики для мирян. Последователи этих центров, как и сами учителя, не могут регулярно встречаться друг с другом и вынуждены прибегать к использованию интернет-технологий. Таким образом

\footnotetext{
${ }^{1}$ COVID-19 [Электронный ресурс] // Ганден Тендар Линг. Московский буддийский центр ФПMT. URL: https:// fpmt.ru/news/covid-19/ (дата обращения: 30.01.2021).

${ }^{2}$ Специальное послание Его Святейшества Далай-ламы в связи с пандемией короновирусной инфекции [Электронный ресурс] // Сохраним Тибет! Тибет, Далай-лама, буддизм. 2020, 30 марта. URL: http://savetibet. ru/2020/03/30/dalai-lama-news.html (дата обращения: 30.01.2021).

3 ‘'Buddha would be green’: Dalai Lama calls for urgent climate action [Электронный ресурс] // The Guardian. 2020, 11 ноября. URL: https://www.theguardian.com/world/2020/nov/11/buddha-would-be-green-dalai-lama-calls-forurgent-climate-action (дата обращения: 30.01.2021).

${ }^{4}$ http://www.khoryug.info/

${ }^{5}$ https://sangha.ru/baikalproject/
} 
буддийские лидеры оказались в ситуации, где существование религии в своем традиционном виде сохраняет множество важных аспектов, однако глобальный характер их деятельности не позволяет им обойтись без использования Интернета для поддержания функционирования сети дхарма-центров.

Нужно отметить, что религиозные правила оказались достаточно гибкими в условиях радикальных внешних перемен, вызванных пандемией коронавируса. Мы видим, что буддистские сообщества не консервативны, они готовы к трансформации традиционных практик, если это в какой-то мере способствует улучшению ситуации в мире. Тем не менее несмотря на то, что цифровизация буддизма в России за последний год резко выросла, многие изменения и распространение цифровой деятельности могут носить временных характер как способ преодоления социальной изоляции.

\section{СПИСОК ЛИТЕРАТУРЫ}

Андросов, В. П. (2011) Индо-тибетский буддизм. Энциклопедический словарь. М. : Ориенталия. 448 с.

Аюшеева, Д. В. (2013) Тибетский буддизм на Западе: особенности и перспективы развития // Евразийство и мир. № 1 . С. 120-125.

Гаврилова, Ю. В., Жиронкина, М. А. (2020) Религии в условиях пандемии COVID-19: опыт России // Общество: философия, история, культура. № 6 (74). С. 36-40. DOI: https://www.doi.org/10.24158/fik.2020.6.6

Дондуков, Б. Ц. (2019) Борьба за «истинность» буддизма: Интернет как пространство диалогов и конфликтов в буддийских сообществах России : дисс.... PhD. Варшавский университет. 206 с.

Нестеркин, С. П. (2009) Основные тенденции развития буддизма в социокультурном пространстве России // Вестник Бурятского государственного университета. Педагогика. Филология. Философия. № 6. С. 16-20.

Померанц, Г. С., Миркина, 3. А. (2006) Набирать снег серебряным кувшином (дзэн-буддизм) // Великие религии мира / науч. ред. тома Е. А. Жукова. М. : Издательский дом Международного университета в Москве. 256 с. С. $144-167$.

Судзуки, Д. Т., Кацуки, С. (1993) Дзэн-буддизм: основы дзэн-буддизма. Практика дзэн. Бишкек : МП «Одиссей». 672 с.

Торчинов, Е. А. (2000) Введение в буддологию : курс лекций. СПб. : Санкт-Петербургское философское общество. 304 с.

Aupers, S., Houtman, D. (2010) Religions of modernity: Relocating the sacred to the self and the digital. Leiden : Brill. $273 \mathrm{p}$.

Berzin, A. (1997) Taking the Kalachakra initiation. Ithaca : Snow Lion Publications. 197 p.

Campbell, H. (2013) Digital religion: Understanding religious practice in new media worlds. London : Routledge. $288 \mathrm{p}$.

Grieve, G. P., Veidlinger, D. (2014) (eds.) Buddhism, the Internet, and digital media: The pixel in the lotus. New York ; London : Routledge. 232 p.

Shoji, R., Matsue, R. (2020) Digital spirituality as paradigm shift? Religious change during the COVID-19 epidemics in Brazil [Электронный ресурc] // SSRN. July 13. URL: https://ssrn.com/abstract=3650566 (дата обращения: 10.02.2021). DOI: https://doi.org/10.2139/ssrn.3650566

Дата поступления: 11.02.2021 2.

\section{REFERENCES}

Androsov, V. P. (2011) Indo-tibetskii buddizm. Entsiklopedicheskii slovar' [Indo-Tibetan Buddhism. Encyclopedic dictionary]. Moscow, Orientaliia. 448 p. (In Russ.).

Ayusheeva, D. V. (2013) Tibetskii buddizm na Zapade: osobennosti i perspektivy razvitiia [Tibetan Buddhism in the West: peculiarities and perspectives of the development]. Evraziistvo i mir, no. 1, pp. 120-125. (In Russ.).

Gavrilova, Yu. V. and Zhironkina M. A. (2020) Religii v usloviiakh pandemii COVID-19: opyt Rossii [Religions in the context of the COVID-19 pandemic: Russia's experience]. Society: Philosophy, History, Culture, no. 6 (74), pp. 36-40. (In Russ.). DOI: https://www.doi.org/10.24158/fik.2020.6.6

Dondukov B. (2019) Bor'ba za «istinnost'» buddizma: Internet kak prostranstvo dialogov $i$ konfliktov $v$ buddiiskikh soobshchestvakh Rossii [The struggle for "trueness" of Buddhism: Internet as a space of dialogues and conflicts in Buddhist communities of Russia] : PhD Diss. University of Warsaw. 206 p. (In Russ.). 
Nesterkin, S. P. (2009) Osnovnye tendentsii razvitiia buddizma v sotsiokul'turnom prostranstve Rossii [The main trends in the evolution of Buddhism in sociocultural space of Russia]. BSU Bulletin. Pedagogy, Philology. Philosophy, no. 6, pp. 16-20. (In Russ.).

Pomerants, G. S. and Mirkina, Z. A. (2006) Nabirat' sneg serebrianym kuvshinom (dzen-buddizm) [To collect snow with a silver jug (Zen Buddhism)]. In: Velikie religii mira [Great religions of the world] / ed. by E. A. Zhukova. Moscow, Publishing House of the International University in Moscow. 256 p. Pp. 144-167. (In Russ.).

Sudzuki D. T. and Katsuki S. (1993) Dzen-buddizm: osnovy dzen-buddizma. Praktika dzen [Zen Buddhism: The basics of Zen Buddhism. Zen practice]. Bishkek, MP “Odissei”. 672 p. (In Russ.).

Torchinov, E. A. (2000) Vvedenie v buddologiiu: kurs lektsii [Introduction to Buddhology: A course of lectures]. St. Petersburg, St. Petersburg Philosophical Society. 304 p. (In Russ.).

Aupers, S. and Houtman, D. (2010) Religions of modernity: Relocating the sacred to the self and the digital. Leiden, Brill. $273 \mathrm{p}$.

Berzin, A. (1997) Taking the Kalachakra initiation. Ithaca, Snow Lion Publications. 197 p.

Campbell, H. (2013) Digital religion: Understanding religious practice in new media worlds. London, Routledge. 288 p.

Grieve, G. P and Veidlinger, D. (2014) (eds.) Buddhism, the Internet, and digital media: The pixel in the lotus. New York, London, Routledge. 232 p.

Shoji, R. and Matsue, R. (2020) Digital spirituality as paradigm shift? Religious change during the COVID-19 epidemics in Brazil. SSRN, July 13. Available at: https://ssrn.com/abstract=3650566 (accessed 10.02.2021). DOI: http://doi. org/10.2139/ssrn.3650566

Submission date: 11.02.2021. 